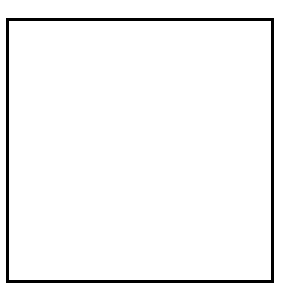

\title{
Grondwetlike waardes, openbare administrasie en die reg op toegang tot omgewingsinligting
}

\author{
Anél Ferreira-Snyman \\ Departement Jurisprudensie \\ Fakulteit Regte \\ Unisa \\ PRETORIA \\ E-pos: ferremp@unisa.ac.za \\ Willemien du Plessis \\ Fakulteit Regte \\ $\mathrm{PU}$ vir $\mathrm{CHO}$ \\ POTCHEFSTROOM \\ E-pos: rmrwdp@puknet.puk.ac.za
}

Abstract

Constitutional values, public administration and the right of access to environmental information

During the previous constitutional dispensation in South Africa the management of information tended to be excessively secretive. This position was changed by section 32 of the Constitution of the Republic of South Africa, 1996.

According to the 1996 Constitution South Africa is a sovereign, democratic state founded on certain values such as human dignity, freedom and equality. The public administration is governed by democratic values and principles such as transparency.

In this article the constitutional values and principles that underlie an open and democratic society are discussed. Thereafter the right of access to information and the legislation that gives content to this right are analysed.

It is concluded that the right of access to information can provide opportunities to the public sector, the private sector and the general public to form partnerships in sharing environmental information in order to fulfil their constitutional obligations. 
Opsomming

Grondwetlike waardes, openbare administrasie en die reg op toegang tot omgewingsinligting

Staatsinligting is gedurende die vorige grondwetlike bedeling as hoogs geheim beskou. Die posisie is gewysig deur artikel 32 van die Grondwet van die Republiek van Suid-Afrika, 1996. Volgens die 1996-Grondwet is Suid-Afrika 'n soewereine, demokratiese staat gebaseer op waardes soos menswaardigheid, vryheid en gelykheid. Die openbare administrasie word onder meer beheers deur die demokratiese waarde van deursigtigheid.

In hierdie artikel word die grondwetlike waardes en beginsels waarop ' $n$ oop en demokratiese samelewing berus, bespreek. Daarna word die reg op toegang tot inligting en die wetgewing wat inhoud aan dié reg verleen, bespreek. Daar word tot die gevolgtrekking gekom dat die reg op toegang tot inligting geleenthede skep vir die openbare sektor, privaatsektor en die algemene publiek om vennootskappe te vorm om omgewingsinligting uit te ruil ten einde hulle grondwetlike verpligtinge na te kom.

\section{Inleiding}

Gedurende die vorige grondwetlike bedeling is die hantering van amptelike inligting deur geheimhouding gekenmerk, wat verhoed het dat die publiek op 'n betekenisvolle wyse aan die besluitnemingsproses kon deelneem. Daar het geen algemene statuut bestaan wat voorsiening gemaak het vir 'n reg op toegang tot inligting in besit van die staat nie. Daar was wel statute wat ' $n$ individu in staat gestel het om toegang tot dokumente en rekords in besit van administratiewe instansies te verkry. Hierdie wetgewing het egter nie ten doel gehad om toegang tot inligting te fasiliteer nie, maar om dit te beperk. Baxter (1984:233) beskryf die gevolge van die regsposisie met betrekking tot toegang tot inligting voor die huidige grondwetlike bedeling soos volg:

Secrecy is an undoubted cause of maladministration, yet it still permeates many facets of the administrative process. The perennial avalance of official reports and statistics tends to conceal the fact that much information of real importance is withheld from the public. This is particularly true in South Africa.

Die Grondwet van die Republiek van Suid-Afrika, 1996 (hierna die 1996Grondwet) het 'n keerpunt in die grondwetlike geskiedenis van SuidAfrika tot gevolg gehad. In die aanhef van die Grondwet word Suid-Afrika as 'n oop en demokratiese samelewing beskryf. Voorts bepaal artikel 1 dat Suid-Afrika 'n soewereine demokratiese staat is wat op sekere waardes gegrond is. (Vgl. 2 hieronder vir 'n bespreking van die grondwetlike waardes.) 
Toegang tot inligting is 'n belangrike kenmerk van enige demokrasie. 'n Reg op toegang tot inligting vervul hoofsaaklik twee funksies in 'n demokrasie: Eerstens stel dit die burger in staat om ingeligte keuses te maak in die uitoefening van sy of haar demokratiese regte en tweedens verseker dit dat staatsgesag op 'n wettige en nie-arbitrêre wyse uitgeoefen word (Klaaren, 1996:24-26). Volgens De Waal, Currie en Erasmus (2001:526) het die 1996-Grondwet ten doel om 'n samelewing te bevorder wat nie deur die outoritêre uitoefening van mag gekenmerk word nie.

'n Deursigtige, verantwoordbare, openbare administrasie wat vir die publiek toeganklik is, is kenmerkend van 'n ware demokrasie aangesien 'n geslote administrasie aanleiding kan gee tot korrupsie en verval (vgl. Ferreira, 2001:5).

Artikel 32 van die 1996-Grondwet verleen gevolglik aan elkeen die reg op toegang tot inligting wat deur die staat en deur privaatpersone gehou word:

(1) Everyone has the right of access to -

(a) any information held by the state; and

(b) any information that is held by another person and that is required for the exercise or protection of any rights.

(2) National legislation must be enacted to give effect to this right and may provide for reasonable measures to alleviate the administrative and financial burden on the state.

Die wetgewing wat kragtens subartikel 2 verorden moes word om aan artikel 32 inhoud te gee, is in die vorm van die Wet op Bevordering van Toegang tot Inligting 2 van 2000 (hierna die WBTTI) gepromulgeer. Dié wet het ten doel om gevolg te gee aan die reg op toegang tot inligting ten einde 'n kultuur van deursigtigheid en verantwoordbaarheid in die openbare sowel as die privaatsektor te bevorder.

Die reg op toegang tot inligting kan op verskeie aangeleenthede betrekking hê. Dit sluit onder meer die reg op toegang tot omgewingsinligting in. Voor die WBTTI gepromulgeer is, het artikel 31 van die Nasionale Wet op Omgewingsbestuur 107 van 1998 (hierna NEMA soos dit in die omgangstaal bekend staan) reeds vir 'n reg op toegang tot omgewingsinligting voorsiening gemaak. Hierdie reg is gebaseer op artikel 32 van die 1996-Grondwet wat met artikel 24 van die Grondwet saamgelees moet word: Artikel 24 van die 1996-Grondwet bepaal soos volg: 
Everyone has the right -

(a) to an environment that is not harmful to their health or wellbeing; and

(b) to have the environment protected, for the benefit of present and future generations, through reasonable legislative and other measures that -

(i) prevent pollution and ecological degradation;

(ii) promote conservation; and

(iii) secure ecologically sustainable development and use of natural resources while promoting justifiable economic and social development.

Artikel 24 plaas die las op die staat om die omgewing deur redelike wetgewende en ander maatreëls te beskerm. Die staat kan egter nie alleen hierdie taak volvoer nie. Dit is die plig van elkeen in Suid-Afrika om toe te sien dat die omgewing vir huidige en toekomstige geslagte beskerm word (Weeramantry, 1994:113). Vir baie jare het regerings op die sogenaamde command and control-maatreëls (maatreëls wat van staatsweë afgedwing word) gesteun om die omgewing te beskerm. Gedurende die laaste paar jaar is daar 'n verskuiwing om management by outsiders (in omgewingsbestuurskringe bekend as $\mathrm{MBO}$ ) in te sluit. Een manier om beheer deur buitestanders te bewerkstellig, is om vennootskappe tussen die staatsadministrasie, die privaatsektor en die algemene publiek te skep. Die reg op toegang tot inligting en dan veral die reg op toegang tot omgewingsinligting kan as 'n effektiewe middel gebruik word om MBO te bewerkstellig.

In hierdie artikel word die grondwetlike waardes wat 'n oop en demokratiese regering ten grondslag lê, eers in die algemeen bespreek. Daarna word die inhoud van die reg op toegang tot omgewingsinligting bespreek as 'n voorbeeld van die wyse waarop die grondwetlike waardes en die genoemde fundamentele regte gekonkretiseer kan word. Laastens word sekere gevolgtrekkings en aanbevelings gemaak.

\section{Grondwetlike waardes}

Die 1996-Grondwet bevat 'n groot aantal bepalings wat met inagneming van sekere waardes geïnterpreteer en toegepas moet word. Ingevolge artikel 1 van die 1996-Grondwet kan 'n lys waardes geïdentifiseer word waarop die Suid-Afrikaanse staat gegrond is. ${ }^{1}$ Indien die teks noukeurig

$1 \quad$ Alhoewel daar 'n uitgebreide lys waardes in artikel 1 van die 1996-Grondwet genoem word, word daar vir die doeleindes van hierdie bydrae slegs gefokus op die invloed 
ontleed word, blyk dit dat slegs sekere begrippe in artikel 1(a)-(c) regstreeks as waardes geëien kan word, naamlik menswaardigheid, nierassigheid, nie-seksisme, die oppergesag van die Grondwet en die heerskappy van die reg. Die ander waardes wat in artikel 1 vermeld word, is geformuleer as prosesse, te wete die bereiking van gelykheid en die uitbou van menseregte en vryhede (Venter, 1998; Venter, 2000:141142). Artikel 7(1) van die 1996-Grondwet bepaal dat die Handves van Regte as 'n hoeksteen van die demokrasie, die demokratiese waardes van menswaardigheid, gelykheid en vryheid bevestig. Ingevolge artikel 39(1) moet die waardes, wat 'n oop en demokratiese samelewing gebaseer op menswaardigheid, gelykheid en vryheid ten grondslag lê, by die uitleg van die Handves van Regte bevorder word.

Die 1996-Grondwet skep die indruk dat demokrasie op sigself nie 'n grondwetlike waarde is nie, aangesien hierdie begrip nooit in die Grondwet as 'n selfstandige waarde aangedui word nie, maar eerder gebruik word om die waardes van menswaardigheid, gelykheid en vryheid te kwalifiseer. Artikel 1 van die 1996-Grondwet bepaal dat SuidAfrika een, soewereine staat is wat op 'n aantal waardes gegrond is. Die waardes wat in artikel 1 genoem word, word dus gekwalifiseer deur die feit dat dit in 'n demokratiese staat geld. Artikel 7 van die 1996-Grondwet bepaal dat die Handves van Regte 'n hoeksteen van die demokrasie in Suid-Afrika is en die demokratiese waardes van menswaardigheid, gelykheid en vryheid bevestig.

Wat die vertolking van die Grondwet, die reg oor die algemeen en die optrede van die regering betref, is dit volgens Venter (1997:225) onvermydelik dat demokrasie as 'n sleutelwaarde aangewend sal moet word. Voorts wys hy daarop dat demokrasie betreklik maklik benut kan word as 'n riglynwaarde by die interpretasie van die reg met betrekking tot die samestelling en funksionering van die owerheidstrukture en hulle prosedures (Venter, 2000: 209-211; vgl. ook Ferreira, 2001 :24-26).

Demokrasie impliseer verantwoordbaarheid en deursigtigheid. 'n Deursigtige, toeganklike en verantwoordbare openbare administrasie is 'n onlosmaaklike element van enige ware demokrasie. Indien openbare amptenare sou versuim om hierdie verantwoordelikheid na te kom, gee dit aanleiding tot die ondermyning van die grondwetlike demokrasie. Die reg op toegang tot inligting is ' $n$ middel om 'n deursigtige regering te bewerkstellig. openbare administrasie uitoefen. 


\section{Toepassing van die grondwetlike waardes op die terrein van die openbare administrasie}

In teenstelling met die geheimhouding, parlementêre soewereiniteit en verontagsaming van fundamentele regte wat die Suid-Afrikaanse grondwetlike bedeling voor 1994 gekenmerk het, stel artikel 195 van die 1996Grondwet dit duidelik dat die openbare administrasie beheers word deur die demokratiese waardes en beginsels wat in die 1996-Grondwet verskans is.

\subsection{Beginsels en waardes}

\subsubsection{Beginsels}

Hoofstuk 10 van die 1996-Grondwet handel spesifiek oor die openbare administrasie. Artikel 195(1) maak voorsiening vir 'n uitgebreide lys beginsels waaraan die openbare administrasie moet voldoen. Hierdie beginsels sluit onder meer die volgende in

- $\quad$ 'n Hoë standaard van beroepsetiek moet bevorder word.

- $\quad$ Die openbare administrasie moet ontwikkelingsgerig wees.

- $\quad$ Dienste moet onpartydig, regverdig, op billike grondslag en sonder vooroordeel gelewer word.

- $\quad$ Aandag moet aan mense se behoeftes gegee word en die publiek moet aangemoedig word om aan beleidsvorming deel te neem.

- Die openbare administrasie moet verantwoordingspligtig wees en deursigtigheid moet bevorder word deur die publiek van tydige, toeganklike en korrekte inligting te voorsien.

Die verwysing in artikel 195 na die demokratiese waardes en beginsels wat in die 1996-Grondwet verskans is, skep 'n verband tussen hierdie riglyne en ander grondwetlike bepalings waarin die frase "oop en demokratiese samelewing" gebruik word. Artikel 195 brei die betekenis van hierdie waardes en beginsels uit deur sekere beginsels te spesifiseer wat relevant is vir die openbare administrasie (Venter, 1997:229). Artikel 195(2) bepaal verder dat hierdie demokratiese waardes en beginsels wat die openbare administrasie beheers, van toepassing is op die openbare administrasie in elke regeringsfeer (nasionaal, provinsiaal en plaaslik), op staatsinstellings en op openbare ondernemings.

\subsubsection{Waardes}

Die waardes waaraan die openbare administrasie gemeet moet word, hou verband met die algemene grondliggende waardes van die Grond- 
wet. Die verband tussen die grondwetlike waardes en die beginsels in artikel 195, vereis dat al die openbare administrasiebeginsels op so 'n wyse toegepas moet word dat dit nie inbreuk maak op die menswaardigheid, vryheid of gelykheid van die individu nie.

\subsubsection{Menswaardigheid}

Die beginsel in artikel 195(1)(d) dat dienste onpartydig, op billike grondslag en sonder vooroordeel aan die publiek gelewer moet word, kan in verband gebring word met die grondwetlike waarde van menswaardigheid. Die openbare administrasie moet dus op so 'n wyse funksioneer dat daar nie onbillik teen iemand gediskrimineer word nie en dat die ingebore waardigheid van elke individu gerespekteer word.

Beginsel 195(1)(e) bepaal dat aandag aan mense se behoeftes gegee moet word en dat die publiek aangemoedig moet word om aan beleidsvorming deel te neem. Volgens Brynard (1996:34) hou deelname ten nouste verband met deursigtigheid en openheid van die besluitnemingsproses in die openbare administrasie ten einde individue in staat te stel om op ' $n$ betekenisvolle wyse daaraan deel te neem en terselfdertyd ook hul waardigheid te bevorder.

\subsubsection{Vryheid}

Van der Vyver (1998:369) meen dat die basiese norm waarop die staatsregtelike bestel van 'n staat gebaseer is, nie na willekeur geselekteer word nie, maar op historiese omstandighede berus. Hierdie omstandighede is dikwels die euwels van die verlede wat tot die nuwe grondwetlike bedeling aanleiding gegee het. In die lig hiervan beskou hy gelyke regsbeskerming en die verbod op diskriminasie as die Grundnorm van die sogenaamde nuwe Suid-Afrika. Hierdie standpunt van Van der Vyver verleen 'n politieke dimensie aan vryheid. Daar word voorgestel dat 'n wyer interpretasie aan vryheid gegee behoort te word, ten einde ook die volgende in te sluit:

- $\quad$ Die vryheid om gebruik te maak van dienste wat deur die openbare administrasie gelewer word.

- $\quad$ Die vryheid om aan beleidsvorming deel te neem en

- die vryheid om toegang te verkry tot inligting in besit van die openbare administrasie (Ferreira, 2001:35).

Beginsel (e) in artikel 195(1) vereis dat die publiek oor die vryheid moet beskik om aan beleidsvorming deel te neem. Hierdie deelname bevorder die deursigtigheid van die besluitnemingsproses en stel die individu sodoende in staat om sy belange te beskerm. Die openbare adminis- 
trasie moet voorts op so 'n wyse funksioneer dat die individu nie van die vryhede ontneem word waarop daar ingevolge die Handves van Regte aanspraak gemaak kan word nie.

\subsubsection{Gelykheid}

Die openbare administrasie moet in die uitoefening van sy handelinge gelyk optree teenoor alle individue en mag nie onbillik teen iemand diskrimineer op grond van die faktore uiteengesit in artikel 9 van die 1996-Grondwet nie. Dit beteken byvoorbeeld dat alle rassegroepe toegelaat moet word om op 'n gelyke grondslag gebruik te maak van die dienste wat deur die openbare administrasie gelewer word.

Die vereiste gestel deur die beginsel in artikel 195(1)(e) dat die publiek aangemoedig moet word om aan beleidsvorming deel te neem, impliseer dat alle persone, ongeag byvoorbeeld geslag of ras, 'n gelyke geleentheid tot hierdie deelname gebied moet word.

Indien individue hulle reg op vryheid om aan beleidsvorming (bv. insake die omgewing) wil uitoefen, is voldoende inligting nodig. Inligting stel 'n individu of groep in staat om te bepaal of die openbare administrasie billik en onpartydig optree. In die verlede is arm mense byvoorbeeld benadeel deurdat hulle menswaardigheid en reg op gelyke behandeling misken was by die plasing van industrieë en afvalterreine. As hulle voldoende inligting gehad het, sou hulle hierdie optrede kon voorkom het en sodoende hulle menswaardigheid en reg op gelyke behandeling kon afdwing (vgl. 5).

\section{Samevatting}

Die 1996-Grondwet is dus gebaseer op die demokratiese waardes van menswaardigheid, gelykheid en vryheid wat die grondslag lê vir die interpretasie van die Handves van Regte. Die bevordering van hierdie demokratiese waardes is afhanklik van 'n verantwoordbare en deursigtige openbare administrasie. Een van die wyses waarop verantwoordbaarheid en deursigtigheid bewerkstellig kan word, is deur middel van die reg op toegang tot inligting. Die reg op toegang tot inligting bevestig die burger se demokratiese reg om aan die regeringsproses deel te neem. Wetgewing wat voorsiening maak vir 'n reg op toegang tot inligting, maak dialoog tussen die staat en die individu moontlik en stel die individu nie slegs in staat om 'n belangrike bydrae tot sosiale en politieke verandering te lewer nie, maar ook om by te dra tot die beskerming van die omgewing. Die konkretisering van die grondwetlike waardes en beginsels soos deursigtigheid in artikel 195 van die 1996Grondwet sal nie alleen effektiewe en behoorlike staatsadministrasie 
verseker nie, maar ook 'n belangrike bydrae tot die bevordering van konstitusionalisme en regstaatlikheid lewer. Die verhouding tussen die staat en die individu kan net baat vind by sodanige ontwikkeling.

Hierna word die reg op toegang tot omgewingsinligting bespreek as 'n voorbeeld van die wyse waarop die grondwetlike beginsel van deursigtigheid en die grondwetlike waardes van vryheid, menswaardigheid en gelykheid gekonkretiseer kan word.

\section{Reg op toegang tot omgewingsinligting}

\subsection{Algemeen}

Die belang van die beskikbaarheid van omgewingsinligting is tydens die VN-Konferensie oor Omgewing en Ontwikkeling in Rio de Janeiro bespreek. Beginsel 10 van die Rio-Deklarasie maak voorsiening vir die reg op toegang tot omgewingsinligting (Hallo, 1993:50). Agenda 21 bevat ook verskeie verwysings na die reg op toegang tot inligting en openbare deelname. (Die relevansie van die Rio-Konferensie het weer na vore gekom tydens die Wêreldbyeenkoms op Volhoubare Ontwikeling wat in Augustus 2002 in Johannesburg plaasgevind het.)

Die reg op toegang tot omgewingsinligting handel onder andere oor mense se deelname aan die besluitnemingsproses aangaande die beskerming van die biosfere waarvan hulle deel vorm. Die reg op toegang tot omgewingsinligting het derhalwe betrekking op sowel die individuele as die openbare belang (Cossiga, 1992:16). Die toepassing van die reg op 'n skoon en gesonde omgewing kan die afweeg van verskillende belange vereis. Die reg op 'n skoon en gesonde omgewing moet byvoorbeeld opgeweeg word teen industriële ontwikkeling. Die belang van die beginsel van deursigtigheid moet opgeweeg word teen die noodsaak vir die beskerming van handelsgeheime (Cossiga, 1992:16).

Die erkenning van 'n reg op toegang tot omgewingsinligting waarborg nie die beskerming van die omgewing nie, maar kan as 'n middel gebruik word om handelinge te kontroleer wat skadelik vir die omgewing mag wees. Hierdie reg kan privaatmaatskappye of industrieë indirek dwing om betyds voorsorgmaatreëls teen byvoorbeeld besoedeling te tref (Kindler, 1993:79). Hegele (1993:171) beskou 'n reg op toegang tot inligting as 'n Druckmittel eerder as 'n beheermaatreël. Dit is egter moeilik om die een van die ander te onderskei (vgl. ook Turiaux, 1994:46; Du Plessis, 1999b:94-95). 
5.2 Artikel 32 van die Grondwet, artikel 31 van NEMA en die WBTTI

Ingevolge artikel 32 van die 1996-Grondwet het elkeen 'n reg op toegang tot inligting teenoor sowel openbare as privaat persone of instansies (vgl. 1 hierbo). Artikel 31 van NEMA bepaal soos volg:

Every person is entitled to have access to information held by the State and organs of state which relates to the implementation of this Act and any other law affecting the environment, and to the state of the environment and actual and future threats to the environment, including any emissions to water, air or soil and the production, handling, transportation, treatment, storage and disposal of hazardous waste and substances;

(b) organs of state are entitled to have access to information relating to the state of the environment and actual and future threats to the environment, including any emissions to water, air or soil and the production, handling, transportation, treatment, storage and disposal of hazardous waste held by any person where that information is necessary to enable such organs of state to carry out their duties in terms of the provisions of this Act or any other law concerned with the protection of the environment or the use of natural resources;

Die WBTTI daarteenoor maak voorsiening vir 'n algemene reg op toegang tot inligting in besit van 'n openbare liggaam (artikel 11) en 'n privaatliggaam (artikel 50). Die aanhef van die wet bepaal dat die wet 'n menseregtekultuur en sosiale geregtigheid moet bevorder, vrywillige en verpligte meganismes moet skep om inligting vinnig, goedkoop en moeiteloos te verkry, deursigtigheid en aanspreeklikheid moet bevorder, effektiewe bestuur moet bewerkstellig en verseker dat die algemene publiek aan besluitneming wat hulle regte kan raak, kan deelneem en dit kan ondersoek (artikel 9). 'n Wyse waarop artikel 32 byvoorbeeld bevorder kan word, is deur vennootskappe tussen die openbare en privaatsektore asook tussen dié sektore en die publiek (vgl. 5.3).

Sowel NEMA as die WBTTI kan gebruik word om inligting te bekom. Die bestaan van die twee wette kan egter potensiële konflik tot gevolg hê, aangesien die WBTTI onder andere meer gronde vir die weiering van toegang tot inligting as artikel 31 van NEMA bevat. Soortgelyke probleme kom in die VSA en Nederland voor waar inligting in terme van een wet geweier word wat in terme van 'n ander wet geopenbaar sou word (vgl. Du Plessis, 1997:136-137; Du Plessis, 1999a:100-101). Alhoewel daar reeds in Nederland gepoog is om die verskillende wette in ooreenstemming met mekaar te bring, was hierdie pogings nie geslaagd nie (Du Plessis, 1999a:40). Die verskille tussen NEMA en die WBTTI is egter tot 
op hierdie stadium nog nie in Suid-Afrika ondervang nie (Du Plessis, 1998:136).

Ten einde te bepaal watter van die twee wette die belange van die aansoeker, die publiek, 'n openbare liggaam, 'n privaatliggaam of deursigtigheid die beste sal dien, word 'n vergelyking tussen die verskillende wette gemaak:

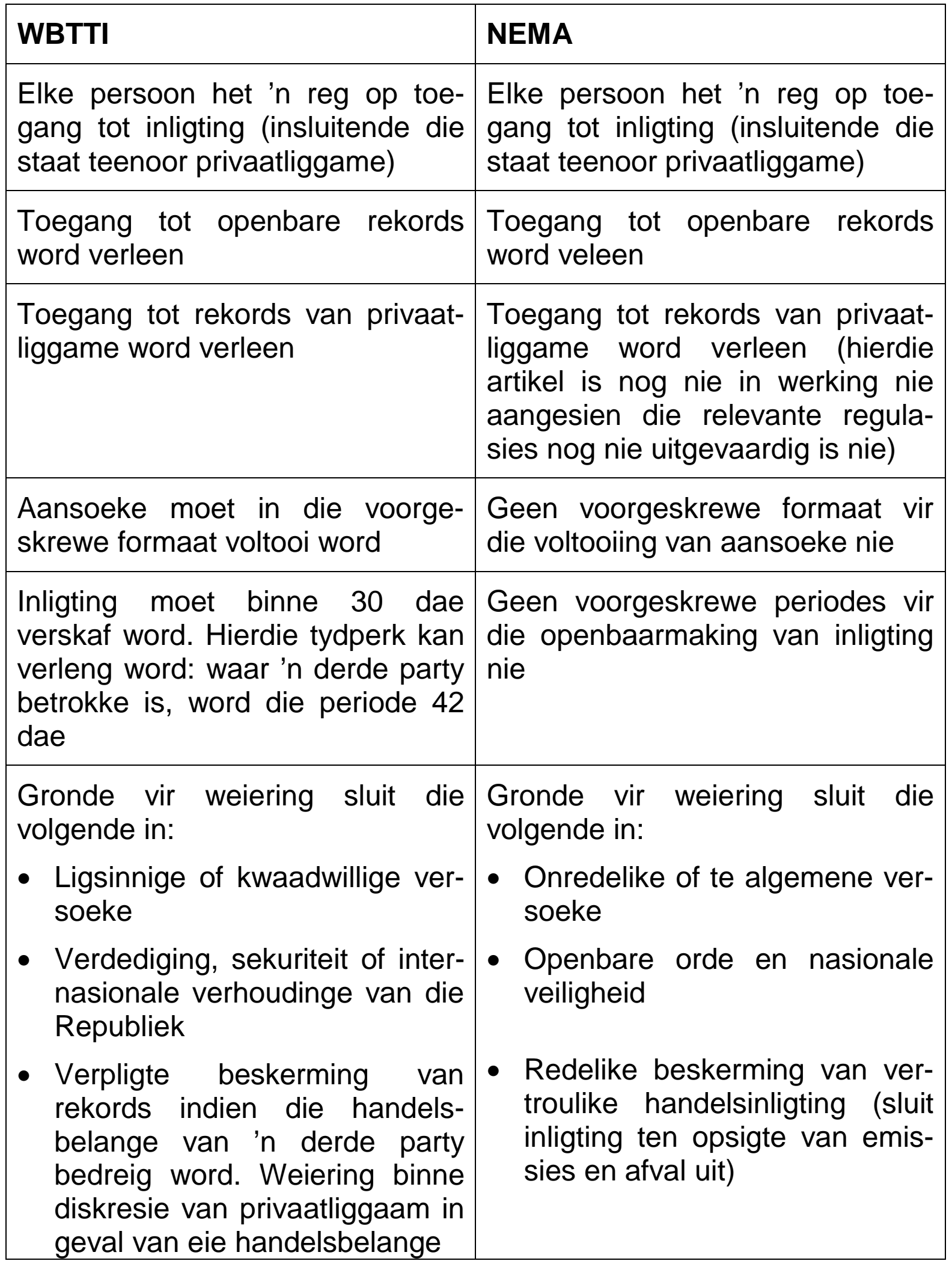


- Verpligte beskerming van privaatheid van 'n derde party

- Ander: Inligting met betrekking tot die SA Inkomstediens, veiligheid van individue, beskerming van eiendom, ens.

Deurhaling van vertroulike inligting is moontlik

Kennis moet aan derdes gegee word dat hulle inligting geopenbaar kan word

Geen beskerming vir alarmmakers (whistle-blowers) - beskerming geleë in die Wet op die Beskerming van Openbaarmaking van Inligting 26 van 2000

Verpligte openbaarmaking in geval van omgewingskade of oortreding van ' $n$ wet

Geen definisie van omgewingsinligting word verskaf nie
- Redelike beskerming van persoonlike privaatheid word verleen
Geen bepaling in hierdie verband nie

Geen bepaling in hierdie verband nie

Beskerming van alarmmakers (whistle-blowers) word gereël
Geen bepaling in hierdie verband nie
Inligting oor uitlate en afval is nie geheim nie

Uit hierdie vergelyking blyk dit dat dit tot voordeel van die aansoeker sal wees om artikel 31 van NEMA te gebruik ten einde omgewingsinligting van die staat te bekom. In die WBTTI is meer gronde vir weiering wat deur die staat gebruik kan word om die openbaarmaking van inligting te vermy. Indien ' $n$ aansoeker egter inligting van 'n privaatinstansie wil ontvang, sal 'n aansoek in terme van die WBTTI eerder in sy of haar guns wees. As 'n staatsdepartement inligting van 'n privaatliggaam wil verkry, kan van albei wette gebruik gemaak word. Dit sal egter vir die staat makliker wees om NEMA te gebruik omdat daar nie, soos deur artikel 50(2) van die WBTTI vereis word, deur die staat bewys hoef te word dat die aansoek in openbare belang is nie. Privaatliggame kan ook nie beweer dat inligting met betrekking tot hulle uitlate en afval vertroulike handelsinligting is nie. Ingevolge NEMA hoef derde partye nie in kennis gestel te word van die aansoek om toegang tot inligting nie.

Aangesien daar nie ' $n$ voorgeskrewe formaat vir die voltooiing van die aansoek of voorgeskrewe tydsduur vir die openbaarmaking van inligting 
in NEMA vermeld word nie, kan dit langer neem om die inligting van die betrokke instansie te ontvang. Dit is egter moontlik dat die howe die WBTTI in hierdie verband as rigtinggewend kan beskou. In soverre redes vir 'n administratiewe besluit as inligting beskou word, sal daar ook geruik gemaak kan word van die Wet op die Bevordering van Administratiewe Geregtigheid 3 van 2000. Ingevolge artikel 5 van hierdie wet moet 'n persoon se aansoek om redes vir administratiewe optrede binne 90 dae na ontvangs van die aansoek verskaf word. Artikel 9 bepaal dat hierdie tydperke óf beperk óf uitgebrei kan word. (Vgl. Ferreira, 2001:4850 vir 'n bespreking van die onderskeid tussen inligting en redes.)

Sowel NEMA as die WBTTI ondersteun die waarde van demokrasie en die beginsel van deursigtigheid in die Grondwet. Indien hierdie wetgewing en spesifiek die gronde vir die weiering van toegang tot inligting nie korrek geïnterpreteer of toegepas word nie, sal dit die ondermyning van hierdie waardes en beginsels in die 1996-Grondwet tot gevolg hê.

Die vraag is egter op welke wyse die afdwinging van die reg op toegang tot omgewingsinligting bevorder kan word.

\subsection{Vennootskappe}

Die deelname van die publiek in omgewingsaangeleenthede het gedurende die laaste paar jaar deel van regsprosedures geword. Nie alleen is openbare deelname ' $n$ voorvereiste vir omgewingsbestuur, omgewingsinvloedstudies en omgewingsamewerkingsooreenkomste nie (artikels 2(4)(f), 23(2)(d) en 35(2)(b) van NEMA; Goewermentskennisgewing $\mathrm{R} 1182$ en R1183 in Staatskoerant 18261 van 1997-09-05), maar is deursigtigheid ook ingesluit in artikel 195(1)(d) en (e) van die 1996Grondwet as 'n beginsel van die openbare administrasie (vgl. 3.1.1).

Toegang tot omgewingsinligting kan die positiewe ontwikkeling van 'n deursigtige eerder as 'n geheimsinnige bestuursklimaat tot gevolg hê. Die publiek en privaatinstansies (bv. 'n myn en staalfabriek) se rol in omgewingsaangeleenthede sal versterk word as die implementering van omgewingsbeleid met die staat bespreek kan word. Dit kan ook privaat instansies dwing om stappe te neem om hul omgewingsvoldoening te verbeter (Hallo, 1993:50).

Ten einde behoorlik aan die besluitneming en beleidsformulering te kan deelneem, is inligting nodig. Individue kan slegs oor die implikasie van handelinge vir die omgewing besluit indien hulle oor voldoende inligting beskik (Weeramantry, 1994:113).

Soos reeds vermeld, kan die regering nie alleen omgewingsvolhoubaarheid verseker nie. State het vroeër op sogenaamde command and 
control-maatreëls gesteun ten einde die omgewing te beskerm. Hierdie maatreëls het egter geblyk oneffektief te wees. 'n Fundamentele beginsel van moderne omgewingsbestuur hou verband met die insluiting van meervuldige meganismes en metodes wat buitestanders in staat stel om aan omgewingsbestuur deel te neem. Hierdie metodes sluit die volgende in: command and control, siviel-gebaseerde metodes, ekonomiese instrumente, ooreenkomste en geskilbeslegtingsmeganismes (Nel \& Du Plessis, 2001:13-17). Openbare deelname en die reg op toegang tot inligting is voorbeelde van siviel-gebaseerde instrumente.

Een van die doelwitte van NEMA is om samewerkende bestuur (cooperative governance) daar te stel. Samewerkende bestuur sluit meer as die blote samewerking tussen verskillende vlakke van regering of tussen staatsdepartemente onderling in. Dit behels ook, soos algemeen daarna verwys word, as bestuur deur buitestanders of MBO.

'n Geïntegreerde MBO-program hou verband met die verhouding tussen die gemeenskap buite die formele regeringstrukture, nie-regeringsorganisasies, gemeenskapsgebaseerde organisasies en privaatinstansies (in die sin van selfregering - Nel \& Du Plessis, 2001:11).

Nel en Du Plessis (2001:17) meen dat die grondslag vir die gedagte soos volg is (sien ook Landau, 1960:346-358; Taylor, 1984):

Support for the deployment of multiple subsystems in environmental framework legislation is to be found in the general theory of environmental impact assessment systems in terms of the redundancy and insider-outsider hypotheses.

Waarop dit neerkom, is dat as die een stelsel, byvoorbeeld die command and control-subsisteem faal om die omgewing te beskerm, een van die ander subsisteme, byvoorbeeld ekonomiese instrumente, ooreenkomste of die bemagtigde publiek hierdie taak kan oorneem. Die teenoorgestelde is egter ook waar. Twee of meer subsisteme kan mekaar komplementeer en versterk om die gewensde resultaat te bewerkstellig (Wandesforde-Smith \& Kerbavaz, 1988:161-191). Binnepersone het soms inligting oor bepaalde aangeleenthede, maar het nie die mandaat of die geleentheid om burokratiese optrede te beveg nie. Buitepersone aan die ander kant het die motivering om burokratiese optrede te bevraagteken, maar het nie noodwendig die inligting om hulle standpunte te ondersteun nie (Taylor, 1984:52). Buitepersone kan dan toegang tot inligting kry, terwyl binnepersone toegang tot deskundigheid en ondersteuningstels verkry wat in staat is om bepaalde aangeleenthede reg te stel (Taylor, 1984). Nel en Du Plessis (2001:19) verduidelik verder soos volg: 
The redundant nature of multiple outsider structures also tends to serve as mutual support or emergency support systems. At least one outsider subsystem is bound to succeed, where others may fail, while it also provides an informal system of backup reliability in an otherwise fallible command and control system

Hierdie teorie beklemtoon die belangrikheid daarvan dat die openbare sektor, die privaatsektor en die algemene publiek vennootskappe moet vorm wanneer die omgewing ter sprake is. Nie alleen behoort die openbare sektor inligting oor die omgewing met bepaalde instansies te deel nie, maar behoort hulle oor die algemeen inligting aan die privaatsektor en die algemene publiek te verskaf. Die WBTTI skep alreeds indirek vennootskappe tussen die openbare sektor, die privaatsektor en die algemene publiek aangesien sowel die openbare as die privaatsektor gedwing word om inligting te verskaf oor omgewings-, gesondheids- en openbare risiko's (vgl. 5.2 hierbo).

Indien die openbare sektor inligting oor omgewingskade of potensiële omgewingskade van die privaatsektor en die algemene publiek ontvang, stel dit hulle in staat om betyds te reageer ten einde volhoubare ontwikkeling te bewerkstellig. Aan die ander kant kan die algemene publiek, as hulle inligting tot hulle beskikking het, die openbare of privaatsektor dwing om betyds op te tree en sodoende omgewingskade te voorkom. As die privaatsektor die vloei van omgewingsinligting van en na belanghebbende en geaffekteerde partye behoorlik kan bestuur, sal 'n unieke vennootskap bewerkstellig word. Die gemeenskap sal byvoorbeeld weet met watter omgewingsprobleme 'n betrokke maatskappy worstel en wat hulle doen om die probleem te ondervang. Die maatskappy kan op sy beurt inligting van die publiek ontvang oor omringende omgewings- en gesondheidstoestande en dan dienooreenkomstig optree. Sodanige vennootskap kan ook misverstande en verkeerde persepsies oor besoedelingsbeheer deur industrieë uitskakel.

Hierdie vennootskappe kan bydra tot die bevordering van die grondwetlike waardes van menswaardigheid, gelykheid en vryheid asook die beginsel van deursigtigheid soos vereis deur die 1996-Grondwet.

\section{Gevolgtrekking}

In teenstelling met die geheimhouding en verontagsaming van fundamentele regte wat die Suid-Afrikaanse grondwetlike bedeling voor 1994 gekenmerk het, stel die aanhef van die 1996-Grondwet dit duidelik dat Suid-Afrika 'n oop en demokratiese samelewing is. Ingevolge artikel 1 kan 'n lys van waardes waarop die Suid-Afrikaanse staat gegrond is, geïdentifiseer word. Die demokratiese waardes en beginsels waaraan 
die openbare administrasie kragtens artikel 195 moet voldoen, hou verband met hierdie algemene grondliggende waardes van die 1996Grondwet. Sommige van die beginsels kan deur bepaalde fundamentele regte in die Handves van Regte gekonkretiseer word. So kan die beginsel van deursigtigheid afgedwing word op grond van die fundamentele reg op toegang tot inligting in artikel 32 van die Grondwet en die wetgewing daarkragtens uitgereik. Die reg op toegang tot inligting is ook noodsaaklik ten einde die reg op 'n omgewing wat nie skadelik vir die mens gesondheid of welstand is nie (vgl. artikel 24 van die Grondwet), na behore te kan afdwing.

Die demokratiese waardes van menswaardigheid, gelykheid en vryheid hou direk verband met die reg op toegang tot inligting. Die openbare administrasie is verplig om na die behoeftes en belange van die mense in sy staatsgebied om te sien. Die bevordering van hierdie behoeftes en belange moet op 'n deursigtige wyse geskied. Een van die pligte van die openbare administrasie is onder meer om toe te sien dat 'n gesonde en skoon omgewing wat nie skadelik vir mense se gesondheid of welsyn is nie, bestaan. ' $n$ Persoon se menswaardigheid en welstand is direk afhanklik van die omgewing waarin hy of sy funksioneer. Ongelykheid en omgewingsongeregtigheid word bewerkstellig indien sekere individue gedwing word om in skadelike omgewings te woon of waar die owerheid versuim om 'n gesonde omgewing te verseker.

Die openbare administrasie het vir jare gesteun op die sogenaamde command and control-sisteem om die omgewing te beskerm. Hierdie metode het geblyk oneffektief te wees. Daar is meer en meer tot die besef gekom dat die owerheid nie in staat is om alleen na die omgewing om te sien nie. Die algemene publiek het ook hulle verantwoordelikheid begin besef om toe te sien dat die omgewing beskerm word, asook om hulle demokratiese regte af te dwing. Die idee van management by outsiders is ' $n$ middel wat gebruik kan word om toe te sien dat die openbare administrasie sy verpligtinge nakom. Een van die instrumente van management by outsiders is die reg op toegang tot inligting wat gebaseer is op die demokratiese waarde van vryheid en die beginsel van deursigtigheid. Elke indidivu beskik dus oor die reg om die openbare administrasie se optredes te kontroleer en toe te sien dat omgewingsvolhoubaarheid bewerkstellig word.

Sowel NEMA as die WBTTI skep die moontlikheid om unieke vennootskappe tussen die openbare en privaatsektor sowel as die algemene publiek te bewerkstellig ten einde 'n vrye vloei van omgewingsinligting te verseker. Sodanige openbaarmaking van inligting behoort nie alleen 'n beter verstandhouding tussen die verskillende rolspelers tot gevolg te hê nie, maar behoort te verseker dat belangrike inligting ten minste een van 
die sektore bereik wat omgewingskade en gesondheidsrisiko's kan voorkom.

Deursigtigheid kan ook omgewingsgeregtigheid bewerkstellig en sodoende bydra tot die bevordering van die demokratiese waardes van menswaardigheid, gelykheid en vryheid.

Die reg op toegang tot inligting wat in die vennootskappe tussen die verskillende rolspelers gebruik word, het definitiewe voordele, maar daar bestaan ook steeds bepaalde probleme. Een van die probleme is om 'n kultuur van deursigtigheid en vertroue tussen die verskillende sektore van die Suid-Afrikaanse samelewing te bewerkstellig. Indien die waardes en beginsels in die Grondwet wat deursigtigheid ten grondslag lê, geïgnoreer word, kan die ou waardes van ondeurdringbaarheid, geheimhouding en manipulasie weer die norm word. Indien dit gebeur, sal dit die fundamentele regte van toegang tot inligting en 'n omgewing wat nie skadelik vir 'n persoon se gesondheid en welstand is nie, vir die individu betekenisloos maak.

\section{Bibliografie}

BAXTER, L. 1984. Administrative Law. Kenwyn : Juta.

BRYNARD, D.J. 1996. Administratiewe geregtigheid: moontlikheid of onwaarskynlikheid? Suid-Afrikaanse Instituut vir Publieke Administrasie, 31(1):23-37.

COSSIGA, F. 1992. Umweltschutz und Informationsrecht der Verfassungschutz der allgemeinen Interessen. Bonn : Bouvier Verlag.

DE WAAL, J., CURRIE, I. \& ERASMUS, G. 2001. The Bill of Rights Handbook. 4e uitg. Kenwyn : Juta.

DU PLESSIS, W. 1997. Right to environmental information in the USA. South African Journal for Environmental Law and Policy, 5(1):115-139.

DU PLESSIS, W. 1998. 'n Reg op omgewingsinligting. Potchefstroom : PU vir CHO. (M.A.-verhandeling.)

DU PLESSIS, W. 1999a. 'n Reg op omgewingsinligting in Nederland. Stellenbosch Law Review/Regstydskrif, 10(1):36-55.

DU PLESSIS, W. 1999b. Enforcement of environmental rights by way of a right to information. Obiter, 20(1):92-112.

FERREIRA, M.P. 2001. Die openbare administrasie en die reg op toegang tot inligting. Potchefstroom : PU vir CHO. (LL.M.-verhandeling.)

HALLO, R.E. 1993. Openbaarheid van milieugegevens: een transatlantische beschouwing. (In Van den Broek, J.H.G., Van der Meijden, D. \& Hallo, R.E., red. Openbaarheid van milieurelevante bedrijfsgegevens. Zwolle : Willink. p. 49-82.)

HEGELE, D. 1993. Thesen. (In Hegele, D. \& Röger, R. Umweltschutz durch Umweltinformation. Berlin : Berlin Verlag. p. 169-172.)

KINDLER, K. 1993. Umweltinformation in gesellschaftlichen Spannungsfeld Chancen und Grenzen einer Umweltinformationsrichtlinie als Instrument zielgerichteter Umweltpolitik. (In Hegele, D. \& Röger, R. Umweltschutz durch Umweltinformation. Berlin : Berlin Verlag. p. 63-81.)

KLAAREN, J. 1996. Access to information. (In Chaskalson, M. e.a., red. Constitutional Law of South Africa. 5de uitg. Kaapstad : Juta. p. 24(1)-24(25).) 
LANDAU, M. 1960. Redundancy, rationality and the problem of duplication and overlap. Public Administration Review, 20:346-358.

NEL, J. \& DU PLESSIS, W. 2001. An evaluation of NEMA based on a generic framework for environmental framework legislation. South African Journal of Environmental Law and Policy: 1-37.

TAYLOR, S. 1984. Making bureaucracies think: the environmental impact strategy of administrative reform. California : Stanford University Press.

TURIAUX, A. 1994. Zugangsrechte zu Umweltinformationen nach der EG-Richtlinie 90/313 und dem deutschen Verwaltungsrecht. Frankfurt : Lang.

VAN DER VYVER, J.D. 1998. Gelykberegtiging. Tydskrif vir Hedendaags RomeinsHollandse Reg, 32(4):367-399.

VENTER, F. 1997. Implications of the Constitution for Public Administration. SuidAfrikaanse Instituut vir Publieke Administrasie, 61(3):221-231.

VENTER, F. 1998. Die betekenis van die bepalings van die 1996-Grondwet. Potchefstroom Elektroniese Regstydskrif. [Web:]

http://www.puk.ac.za/lawper/1998-1/venter-die.html [Datum van gebruik: 18 Nov. 1998].

VENTER, F. 2000. Constitutional comparison Japan, Germany, Canada and South Africa as Constitutional states. Kaapstad : Juta.

WANDESFORDE-SMITH, G. \& KERBAVAZ, J. 1988. The co-evolution of politics and policy: elections, entrepreneurship and EIA in the United States. (In Wathern, P. Environmental Impact Assessment and Practice. London : Uhwin Hyman. p. 161191.)

WEERAMANTRY, C.G. 1994. Access to information: a new human right. The right to know. Asian Yearbook of International Law: 99-125.

\section{Wetgewing}

Grondwet van die Republiek van Suid-Afrika 200 van 1993.

Grondwet van die Republiek van Suid-Afrika, 1996.

Nasionale Wet op Omgewingsbestuur 107 van 1998.

NEMA

kyk Nasionale Wet op Omgewingsbestuur 107 van 1998

WBTTI

kyk Wet op Bevordering van Toegang tot Inligting

Wet op die Bevordering van Administratiewe Geregtigheid 3 van 2000.

Wet op die Bevordering van Toegang tot Inligting 2 van 2000.

\section{Goewermentskennisgewings}

Goewermentskennisgewing R1182-1183 in Staatskoerant 18261 van 1997-09-05

\section{Kernbegrippe:}

konstitusionele waardes

openbare administrasie

toegang tot omgewingsinligting

\section{Key concepts:}

access to environmental information

constitutional values

public administration 